\title{
ANALISIS KIMIA IKAN SAPU-SAPU \\ (Pterygoplichthys pardalis Castelnau 1855) DARI DANAU TEMPE SULAWESI SELATAN, INDONESIA
}

\author{
Hasnidar $^{1 \star}$, Andi Tamsil ${ }^{1}$,Andi Muhammad Akram ${ }^{2}$, Taufik Hidayat ${ }^{3}$ \\ ${ }^{1} J u r u s a n$ Budidaya Perairan Fakultas Perikanan dan Ilmu Kelautan Universitas Muslim Indonesia \\ Jalan Urip Sumoharjo Km. 05, Makassar 90231 Makassar \\ ${ }^{2}$ Jurusan Teknik Sipil Universitas Muslim Indonesia \\ Jalan Urip Sumoharjo Km. 05, Makassar 90231 Makassar \\ ${ }^{3}$ Pusat Teknologi Agroindustri, Badan Pengkajian dan Penerapan Teknologi, Gedung Laptiab Puspiptek \\ Serpong
}

Diterima: 27 Desember 2020/Disetujui: 13 April 2021

${ }^{\star}$ Korespondensi: hasnidar.yasin@umi.ac.id

Cara sitasi: Hasnidar, Tamsil A, Akram AM, Hidayat T. 2021. Analisis kimia ikan sapu-sapu (Pterygoplichthys pardalis Castelnau 1855) dari Danau Tempe Sulawesi Selatan, Indonesia. Jurnal Pengolahan Hasil Perikanan Indonesia. 24(1): 78-88.

\begin{abstract}
Abstrak
Ikan sapu-sapu adalah spesies invasif di Danau Tempe yang populasinya semakin bertambah dan sampai saat ini belum ada upaya pemanfaatannya. Penelitian ini bertujuan untuk menentukan kandungan protein, lemak, serat kasar, abu, air, asam amino dan asam lemak esensial ikan sapu-sapu yang berasal dari Danau Tempe. Parameter uji dilakukan berdasarkan SNI 01-2891-1992 dan menggunakan alat HPLC (High Performance Liquid Chromatography). Hasil uji menunjukkan bahwa kandungan protein, lemak, serat kasar, abu dan air masing-masing sebagai berikut 15,20\%; 6,27\%; 2,14\%; 4,74\%; dan 67,19\%. Selanjutnya kandungan asam amino esensial terdiri dari leusina, arginina, lisina, fenilalanina, treonina, isoleusina, valina, metionina, histidina, dan triptopan sebagai berikut 5,78\%; 5,30\%; 4,55\%; 4,45\%; 3,97\%; $3,44 \% ; 3,39 \% ; 2,42 \% ; 2,09 \%$ dan $0,67 \%$. Kandungan asam lemak esensial terdiri dari asam dekosaheksanoat (DHA), eikosapentanoat (EPA), linolenat (HUFA), linoleate (LA) dan arakidonat (AA) masing-masing sebagai berikut 0,23\%; 0,06\%; dan 0,09\%; 0,10\% dan 0,15\%. Ikan sapu-sapu memiliki kandungan kimia atau zat gizi yang baik, asam amino dan lemak esensial yang lengkap, sehingga dapat direkomendasikan sebagai sumber makanan yang bergizi baik untuk konsumsi masyarakat, maupun untuk bahan pakan ternak dan ikan.
\end{abstract}

Kata kunci: asam amino, asam lemak, esensial, ikan sapu-sapu, protein

\section{Chemical analysis of Amazon sailfin catfish Pterygoplichthys pardalis (Castelnau 1855) from Tempe Lake South Sulawesi, Indonesia}

\begin{abstract}
Amazon sailfin catfish is an invasive species in Lake Tempe whose population is increasing and until now there has been no effort to use it. This study aimed to determine the content of protein, lipid, crude fiber, ash, water, amino acids, and essential fatty acids of Amazon sailfin catfish originating from Lake Tempe. The methods used to obtaine those datas included protein, fat, crude fiber, water, ash, content. Those parameters were based on SNI 01-2891-1992 and using HPLC (High Performance Liquid Chromatography). The results showed that the content of protein, lipid, crude fiber, ash and water were $15.20 \% ; 6.27 \% ; 2.14 \% ; 4.74 \%$; and $67.19 \%$ respectively. Furthermore, the content of essential amino acids consisting of leucine, arginine, lysine, phenylalanine, threonine, isoleusine, valine, methionine, histidine, and tryptophan are as follows 5.78\%; 5.30\%; 4.55\%; 4.45\%; 3.97\%; 3.44\%; 3.39\%; 2.42\%; $2.09 \%$ and $0.67 \%$. The content of essential fatty acids consists of decosahexanoic acid (DHA), eicosapentanoic (EPA), linolenic acid (HUFA), linoleate (LA) and arachidonic (AA) respectively as follows $0.23 \% ; 0.06 \%$; and $0.09 \% ; 0.10 \%$ and $0.15 \%$. Amazon sailfin catfish has a good chemical or nutritional content, complete amino acids and essential fats. Thus, it is recommended as a nutritious food source for public consumption, as well as for animal and fish feed ingredients.
\end{abstract}

Keyword: Amazon sailfin catfish, amino acids, essential, fatty acids, protein 


\section{PENDAHULUAN}

Danau Tempe di provinsi Sulawesi Selatan berada di tiga wilayah kabupaten yaitu masing-masing Kabupaten Wajo, Sidrap, dan Soppeng namun wilayah terbesarnya berada di Kabupaten Wajo. Danau ini termasuk tipologi perairan danau banjiran yaitu dicirikan oleh fluktuasi airnya sangat bervariasi sepanjang tahun antara musim kemarau dan penghujan. Danau Tempe memiliki luas sekitar \pm 1.000 ha pada musim kemarau, volume air sangat sedikit dan hanya ditemukan pada bagian tengah danau saja. Sedangkan pada saat musim hujan luasnya dapat mencapai \pm 30.000 ha, karena air meluap menggenangi wilayah sekitar danau, sungai menyatu dengan danau; dan pada saat normal luasnya hanya sekitar \pm 10.000 ha (Nasution 2015).

Danau Tempe termasuk perairan yang mempunyai tingkat produktivitas yang tinggi, hal tersebut disebabkan banyaknya nutrien yang masuk melalui aliran air dari sungai maupun dari sekitar danau yang merupakan daerah pertanian. Sumbangan nutrien tersebut mendorong peningkatan produksi fitoplankton, tanaman air, zooplankton, dan hewan-hewan avertebrata air yang menjadi sumber makanan bagi ikan (Junk et al. 1989; Gehrke 1990; de Carvalho et al. 2001), oleh karena itu Danau Tempe mendapat julukan "mangkuk ikan" karena produksi ikannya yang sangat tinggi. Menurut beberapa sumber dan berdasarkan pantauan di lapangan, beberapa tahun terakhir ada kecenderungan produksi ikannya semakin menurun. Samuel et al. (2010), melaporkan bahwa produksi ikan tahun 1955 sebesar 6.500 ton; tahun 1977 sebesar 4.500 ton: tahun 2010 sebesar 1.427 ton. Selain terjadi penurunan produksi ikan, diduga jenis ikan di Danau Tempe juga mengalami pengurangan. Jumlah jenis ikan yang tertangkap yang dilaporkan Samuel et al. (2010) terdapat 12 jenis ikan, selanjutnya Nasution (2015) melaporkan terdapat 9 jenis ikan yang tertangkap dan didominasi oleh ikan sepat siam (Trichopodus pectoralis) dan nilem (Osteochilus vittatus). Penurunan produksi dan jumlah jenis ikan diduga disebabkan beberapa faktor antara lain: penangkapan ikan yang intensif; kualitas perairan yang menurun akibat pencemaran yang berasal dari limbah pertanian, limbah hasil pengolahan sutra dan limbah rumah tangga; sedimentasi; adanya gulma air (eceng gondok) yang semakin padat dan permasalahan lain yang cukup serius adalah hadirnya spesies asing invasif (SAI) yaitu ikan sapu -sapu.

Ikan sapu-sapu (Pterygoplichthys spp.) berasal dari Sungai Amazon di Amerika Selatan (Wahyudewantoro 2018), ikan ini telah menyebar ke berbagai negara tropis termasuk Indonesia, Malaysia, Filipina melalui kolektor ikan hias (Jumawan et al. 2016). Kolektor ikan hias memanfaatkan ikan sapusapu sebagai pembersih kaca akuarium, saat ini ikan tersebut telah menjadi invasif di alam (Wu et al. 2011). Thalathiah dan Palanisamy (2004) melaporkan dampak negatif kehadiran ikan sapu-sapu pada famili Cyprinidae di Malaysia, famili Loricariidae di Singapura (Nelson 2006), berbagai jenis ikan dan moluska di sepanjang DAS Ciliwung (Hadiaty 2011, Wahyudewantoro dan Rachmatika 2016; Muhtadi et al. 2017); di Sungai Cilutung (Rachmatika dan Wahyudewantoro 2006).

Populasi ikan sapu-sapu di Danau Tempe beberapa tahun terakhir berkembang sangat pesat karena ikan ini mampu beradaptasi dengan baik pada lingkungan danau; tidak mempunyai predator; tidak dikonsumsi oleh masyarakat dan pemanfaatan lainnya belum terinformasikan. Penampakan yang menyeramkan dan ditutupi oleh sisik yang keras sehingga ikan ini tidak dikonsumsi masyarakat. Chaichana dan Jongphadungkiet (2012) melaporkan bahwa di Thailand satusatunya cara untuk mengurangi kelimpahan ikan sapu-sapu di perairan adalah dengan mengonsumsi ikan tersebut yang ditangkap oleh nelayan di sungai-sungai. Hal yang sama di Indonesia, di beberapa tempat ikan sapusapu telah dijadikan sebagai bahan pembuatan berbagai jenis panganan antara lain otak-otak (Nurjanah 2005), empek-empek (Trisnawati 2007), siomay dan bakso (Dhika 2013). Selain dapat dikonsumsi masyarakat, ikan ini dapat dijadikan sebagai sumber protein hewani pada pembuatan pakan seperti pada ikan patin (Hutasoid et al. 2014); pakan ternak itik (Asnawi 2018).

Ikan sapu-sapu yang berasal dari Danau Tempe dan sekitarnya dapat dikonsumsi 
maupun menjadi bahan baku pakan ternak dan ikan misalnya yang telah dilakukan pada beberapa tempat di Indonesia. Informasi ilmiah tentang komposisi gizi seperti protein, lemak, serat kasar, abu dan kadar air; kandungan asam amino dan asam lemak esensialnya sangat diperlukan dalam rangka pemanfaatannya di masa yang datang. Pemanfaatkan ikan sapu-sapu tersebut diharapkan selain dapat meningkatkan pendapatan masyarakat, populasinya juga dapat terkontrol sehingga populasi ikan-ikan asli di Danau Tempe dapat meningkat. Penelitian ini bertujuan untuk menentukan kandungan protein, lemak, serat kasar, abu, air, asam amino dan asam lemak esensial ikan sapu-sapu yang berasal dari Danau Tempe.

\section{BAHAN DAN METODE Bahan dan Alat}

Ikan sapu-sapu berasal dari Danau Tempe di Kecamatan Tempe, Kabupaten Wajo, Sulawesi Selatan (Figure 1). Bahan dan peralatan yang dibutuhkan dalam analisis kimia yaitu: akuades, kertas saring, katalis selenium, kapas bebas lemak, $\left(\mathrm{H}_{2} \mathrm{SO}_{4}, \mathrm{H}_{3} \mathrm{BO}_{3}\right.$ $2 \%, \mathrm{HCl} \mathrm{0,1} \mathrm{N,} \mathrm{NaOH} 40 \mathrm{~mL}$ ) Merck, (metil merah $0,1 \%$, bromokresol hijau $0,1 \%$, dan pelarut heksana) Sigma, kloroform (p.a.) dan metanol (p.a.), akuades $(\mathrm{NaOH} 0,5 \mathrm{~N}$ dalam metanol, $\mathrm{BF} 3, \mathrm{NaCl}$ jenuh, n-heksana, dan $\mathrm{Na}_{2} \mathrm{SO}_{4}$ anhidrat) Merck, HLPC dan GC (Shimadzu 2000).

\section{Metode Penelitian}

Ikan sapu-sapu segar dibersihkan, ikan disayat pada bagian punggung (kanan dan kiri) sirip punggung dari pangkal belakang kepala hingga pangkal ekor dengan menggunakan pisau. Pada ujung kepala dan ekor, sayatan diteruskan ke arah perut hingga terbentuk dua sisi potongan daging abdomen yang membuka. Pengambilan daging dilakukan dengan menggunakan pisau. Rendemen adalah perbandingan antara berat total ikan dengan berat daging yaitu 1:0,25 atau rendemen daging ikan sapu-sapu adalah $\pm 25 \%$. Daging ikan diuji kimia meliputi protein metode Kjeldahl, lemak metode Soxhlet, abu metode pengabuan kering dan air metode kering masing-masing mengikuti standar SNI 01-2891-1992.

Sedangkan untuk analisis asam amino esensial berdasarkan petunjuk Abdullah et al. 2013 sebagai berikut: (1) Tahap hidrolisat protein, ikan dihancurkan kemudian diambil sebanyak $5 \mathrm{~g}$ selanjutnya dihidrolisis menggunakan asam $\mathrm{HCl} 6 \mathrm{~N}$ sebanyak 10 mL. Sampel dipanaskan selama 24 jam dengan suhu $110^{\circ} \mathrm{C}$; (2) Tahap pengeringan, sampel sebanyak $25 \mu \mathrm{L}$ dimasukkan ke dalam tabung uji dan ditambahkan larutan pengering sebanyak $25 \mu \mathrm{L}$. Larutan pengering terbuat dari perbandingan antara metanol:natrium asetat:trietilamina (TEA) yaitu 2:2:1. Selanjutnya sampel dikeringkan selama 1530 menit menggunakan evaporator putar; (3) Tahap derivatisasi, sampel hasil pengeringan ditambahkan larutan derivatisasi sebanyak 25 $\mu \mathrm{L}$. Larutan derivatisasi terbuat dari metanol :picotiocianat (PITC):trietilamina dengan perbandingan 1:1:2. Sampel selanjutnya didiamkan pada suhu ruang selama 20 menit, kemudian ditambahkan $25 \mu \mathrm{L}$ natrium asetat 1 M. Hasil campuran tersebut selanjutnya disaring menggunakan kertas saring Whatman; (4) Tahap Injeksi ke HPLC. Sebelum peralatan

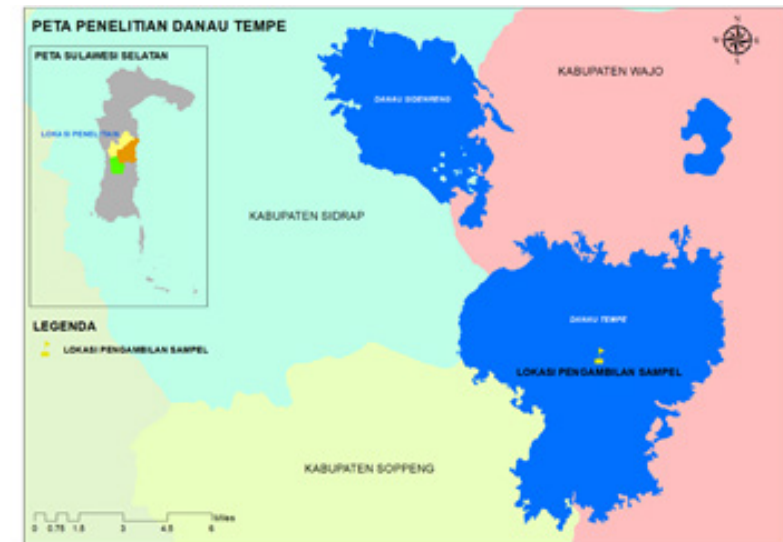

Figure 1 Tempe Lake in Kecamatan Tempe Kabupaten Wajo, South Sulawesi. 
HPLC digunakan terlebih dahulu dibersihkan menggunakan eluen selama 2-3 jam dan syringe dibersihkan dengan akuades. Sampel hasil saringan sebanyak $5 \mu \mathrm{L}$ diinjeksikan ke dalam HPLC selama kurang lebih 25 menit.

Kandungan asam amino sampel diketahui dengan cara terlebih dahulu mengetahui konsentrasi dan luas area standar asam amino dengan menggunakan perlakuan seperti pada sampel. Berikut rumus yang digunakan untuk mengetahui kandungan asam amino (AA) sampel adalah :

$\%$ Asam amino $=[($ Luas area sampel $) \mathrm{x}$ (Konsentrasi standar AA) x (Faktor pengencer) x (Bobot molekul AA) x (100\% Luas area standar) $\mathrm{x}$ (bobot sampel)]

Keterangan:

Konsentrasi standar $\mathrm{AA}=0,5 \mu \mathrm{mol} / \mathrm{mL}$;

Faktor pengenceran $=5 \mathrm{~mL}$;

Bobot molekul dari masing-masing AA (g/ mol).

Kondisi alat HPLC saat berlangsungnya analisis AA sebagai berikut:

suhu $=27^{\circ} \mathrm{C}$ (suhu ruang)

Jenis kolom HPLC: P1 Cotag Amino Acid; kecepatan alir eluen: $0.5 \mathrm{~mL} / \mathrm{menit}$;

tekanan: 3000 psi;

fase gerak: bufer fosfat,

asetonitril detektor/panjang gelombang: fluoresensi/272 $\mathrm{nm}$.

Prosedur untuk mengetahui kandungan asam lemak (Abdullah et al. 2013) sebagai berikut: (1) ekstrak lemak sampel sebanyak 20 mg dimasukkan dalam tabung yang mempunyai tutup teflon, selanjutnya dipanaskan selama 20 menit; (2) hasil ekstrak yang telah dipanaskan ditambahkan larutan $\mathrm{BF}_{3} 20 \%$ sebanyak $2 \mathrm{~mL}$, standar internal sebanyak $5 \mathrm{mg} / \mathrm{mL}$ selanjutnya dipanaskan lagi selama 20 menit; (3) selanjutnya didinginkan, setelah itu ditambahkan $\mathrm{NaCl}$ jenuh sebanyak $2 \mathrm{~mL}$ dan isooktan sebanyak $1 \mathrm{~mL}$, campuran tersebut dikocok supaya merata; (4) Lapisan isooktan yang terbentuk dipindahkan dengan bantuan pipet tetes ke dalam tabung berisi $\mathrm{Na}_{2} \mathrm{SO}_{4}$ anhidrat sebanyak 0,1 g, dan dibiarkan 15 menit; (5) Fase cair yang terbentuk dipisahkan, sedangkan fase minyak yang terbentuk diambil sebanyak 1 $\mu \mathrm{L}$ selanjutnya diinjeksikan ke instrumen GC, sebelumnya dilakukan penginjeksian 1 $\mu \mathrm{L}$ terlebuh dahulu dicampur dengan larutan FAME (Supelco 37 component fatty acid methyl ester mix).

\section{Analisis Data}

Hasil uji kimia ikan sapu-sapu dianalisis secara deskriptif. Kandungan protein, lemak, serat kasar, abu dan air sampel dibandingkan dengan kandungan kimia ikan sampel dengan hasil uji kimia ikan yang sama pada lokasi yang berbeda data yang diperoleh Hasil uji proksimat bertujuan untuk menentukan kuantitas kimia ikan sapu-sapu sebagai sumber gizi, sedangkan untuk uji kualitas ditentukan dengan kelengkapan dan kadar asam amino dan asam lemak esensialnya. Hasil ujinya dibandingkan dengan ikan yang sama di tempat atau habitat yang berbeda.

\section{HASIL DAN PEMBAHASAN Komposisi Kimia}

Hasil uji kimia daging ikan sapu-sapu dari Danau Tempe menunjukkan bahwa kadar protein 15,20\%; lemak 6,27\%; serat kasar 2,14\%; abu 4,74\% dan kadar air 67,19\%. Hasil tersebut menunjukkan bahwa ikan sapu-sapu termasuk ke dalam golongan ikan berprotein sedang 15-20\% (Stansby dan Olcott 1963); tinggi yaitu 8-25\% (Suhartini dan Hidayat 2005), 15-20\% (Nurhayati et al. 2007). Ikan yang memiliki kandungan protein tinggi sangat bermanfaat terhadap kesehatan. Protein ikan berfungsi sebagai zat pembangun jaringan di dalam tubuh (Halver dan Hardy 2002), sumber energi dan pengatur sistem metabolisme (Munthe et al. 2016), pertumbuhan, pemeliharaan jaringan, pembentukan antibodi (Batubara 2009). Protein ikan selain mudah dicerna, juga terdiri dari sejumlah asam amino yang mempunyai pola mendekati pola asam amino tubuh manusia (Suhartini dan Hidayat 2005).

Ikan sapu-sapu memiliki kadar lemak yaitu $6,27 \%$, berdasarkan nilai tersebut maka termasuk golongan ikan yang berlemak sedang yaitu 5-15\% (Sansby dan Olcott 1963); ikan berlemak tinggi yaitu $>5 \%$ (Sun 2006). Ikan memiliki kandungan lemak yang bervariasi, ada yang memiliki kandungan lemak yang tinggi dan ada juga yang rendah, secara umum kandungan lemak ikan berkisar antara 1-20\% 
(Batubara 2009). Menurut Sun (2006), ikan dikategorikan menjadi tiga berdasarkan pada kadar lemak yang dimilikinya yaitu ikan kurus dengan kandungan lemak $<2 \%$, berlemak sedang antara $2-5 \%$, dan berlemak tinggi apabila lemaknya $>5 \%$. Produk perikanan umumnya mengandung asam lemak tak jenuh, kelebihan asam lemak tak jenuh yaitu mudah dicerna oleh tubuh, diperlukan untuk pertumbuhan dan dapat menurunkan kadar kolesterol darah (Adawiyah 2008). Lemak berperan sebagai sumber energi, pelarut vitamin dan sebagai asam lemak esensial (Sumardjo 2006).

Kadar serat ikan sapu-sapu yaitu 2,14\%; ikan bukan termasuk bahan makanan yang banyak mengandung serat seperti sumber makanan nabati. Serat adalah bagian dari makanan yang sulit dicerna dan diserap oleh organ pencernaan, nilai gizinya rendah namun mempunyai fungsi penting yang tidak tergantikan oleh zat lainnya (Kusharto 2006). Serat berperan merangsang gerak peristaltik saluran pencernaan, media mikroba pada usus buntu dan akan menghasilkan vitamin $\mathrm{K}$ dan B12 (Sihite 2013). Selanjutnya dijelaskan bahwa batas maksimum penggunaannya dalam pembuatan pakan tidak lebih dari 5\%.

Ikan memiliki kandungan abu yang berbeda-beda, ikan sapu-sapu mengandung abu sebesar $4,74 \%$. Kandungan abu tersebut tergolong tinggi jika dibandingkan dengan SNI 01-2354-2006 yaitu standar mutu ikan segar kurang dari 2\%. Abu adalah zat anorganik sisa hasil pembakaran suatu bahan organik. Kandungan abu suatu bahan makanan menunjukkan besarnya jumlah mineral dalam bahan tersebut. Kandungan abu total menjadi parameter penentu nilai gizi suatu bahan makanan (Winarno 2008). Arias et al.
(2004) menjelaskan bahwa kandungan abu pada ikan dipengaruhi oleh warna dagingnya. Ikan yang memiliki daging berwarna putih mengandung abu lebih rendah, sebaliknya yang berwarna merah mengandung abu lebih tinggi. Menurut Deman (1977), kandungan abu juga menggambarkan banyaknya mineral yang tidak terbakar menjadi zat yang dapat menguap, ikan yang memiliki daging yang berwarna merah menyimpan banyak mineral dibandingkan daging berwarna putih. Selanjutnya menurut Gultom et al. (2015), penyusun utama mineral dalam tubuh ikan berasal dari komponen penyusun tulang. Berdasarkan pengamatan, ikan sapusapu memiliki daging berwarna merah, sehingga diduga menjadi penyebab tingginya kandungan abu ikan tersebut.

Kandungan air ikan sapu-sapu yaitu $67,19 \%$, kandungan air mempunyai hubungan yang berlawanan dengan kandungan lemak. Ikan yang memiliki kandungan air yang tinggi maka kandungannya lemaknya rendah (Suzuki 1991). Selain itu, kandungan air bahan makanan berpengaruh juga terhadap kandungan proteinnya, semakin tinggi kandungan air maka kandungan protein semakin rendah atau sebaliknya semakin tinggi kadar protein maka akan rendah kandungan airnya (Buckle et al. 1987). Secara umum ikan tergolong memiliki kandungan air yang tinggi yaitu $\pm 70 \%$, daya tahan bahan makanan sangat dipengaruhi oleh kandungan airnya, oleh karena itu ikan termasuk bahan makanan yang mudah rusak. Hasil uji kimia ikan sapu-sapu yang berasal dari Danau Tempe jika dibandingkan dengan uji kimia ikan yang sama pada beberapa perairan tersaji pada Table 1.

Table 1 Chemical test results of Amazon sailfin catfish in several inland waters

\begin{tabular}{lcccc}
\hline \multicolumn{1}{c}{ Amazon sailfin catfish habitat } & \multicolumn{4}{c}{ Parameters } \\
\cline { 2 - 5 } & $\begin{array}{c}\text { Protein } \\
(\%)\end{array}$ & $\begin{array}{c}\text { Lipid } \\
(\%)\end{array}$ & Ash (\%) & $\begin{array}{c}\text { Water } \\
(\%)\end{array}$ \\
\hline Tempe Lake, Kabupaten Wa-jo, South Sulawesi & 15.20 & 6.27 & 4.74 & 67.19 \\
Cirata Reservoir, Kabupaten Purwakarta (Chaidir 2001) & 19.71 & 1.23 & 1.01 & 77.50 \\
Bebanteng River, Bogor (Nurjanah 2005) & 11.97 & 0.03 & 2.51 & 83.16 \\
Bedadung River, Jember (Munandar dan Eurika 2016) & 19.71 & 1.73 & 1.01 & 77.50 \\
Ciliwung River, Jakarta (Elfidasari et al. 2019) & 45.05 & 1.12 & 0.79 \\
\hline
\end{tabular}


Berdasarkan Table 1, terlihat bahwa ikan sapu-sapu memiliki kandungan kimia seperti protein, lemak, abu, kadar air bervariasi berdasarkan perairan tempat hidupnya atau habitatnya. Menurut Ozogul et al. (2007), kandungan kimia daging ikan misalnya protein dan lemak dipengaruhi oleh habitat ikan tersebut hidup. Lingkungan perairan dapat bervariasi antara lain kualitas perairan (Aziz et al. 2013) dan ketersediaan makanan (Bell et al. 2007; Ramlah 2016). Ikan yang mendapatkan porsi makan yang tinggi cenderung mempunyai kandungan lemak yang tinggi pula (Bell et al 2007; Tanamati et al. 2009). Danau Tempe dikategorikan danau yang memiliki produktivitas yang sangat tinggi khususnya pada musim hujan (Nofdianto dan Tanjung 2019). Karena kesuburannya, maka tersedia sumber makanan yang cukup bagi berbagai jenis ikan yang ada di dalamnya. Menurut Kantun et al. (2015), ikan yang hidup di lingkungan yang subur dan kaya akan sumber makanan cenderung memberikan sumber lemak yang tinggi. Kualitas air yang baik menjadi faktor yang menentukan pertumbuhan ikan yang baik, sebaliknya kualitas air yang rendah akan menurunkan daya tahan tubuh ikan sehingga lebih mudah terserang penyakit (Jubaedah et al. 2013).

\section{Asam Amino Esensial}

Daging ikan sapu-sapu mengandung sepuluh jenis asam amino esensial, kesepuluh jenis asam amino tersebut diurut berdasarkan kandungan tertinggi ke rendah disajikan di Table 2.

Hasil pada Table 2 menunjukkan bahwa ikan sapu-sapu memiliki kesepuluh jenis asam amino esensial, dengan demikian ikan sapu-sapu dapat dikatakan memiliki asam amino esensial sempurna (Adawiah 2008). Kandungan asam amino esensial ikan sapusapu relatif tinggi, tetapi lebih rendah jika dibandingkan dengan kebutuhan asam amino yang direkomendasikan oleh $\mathrm{FAO} /$ WHO (Santoso et al. 1996). Asam amino esensial adalah jenis zat gizi makanan yang sangat dibutuhkan oleh tubuh tetapi tubuh tidak dapat memproduksinya sehingga harus disuplai dari luar yaitu melalui makanan. Jenis makanan yang banyak memiliki asam amino esensial adalah ikan.

Jenis leusin ditemukan paling tinggi kandungannya pada ikan sapu-sapu yaitu $5.780 \mathrm{mg} / 100$ g. Leusina mempunyai fungsi menurunkan kadar gula darah; memacu fungsi otak; meningkatkan energi otot; mempercepat penyembuhan luka pascaoperasi (Harli 2008; Vijayan et al. 2016); dan menjaga sistem kekebalan tubuh (Edison 2009). Asam amino tertinggi kedua yaitu arginina dengan kandungan $5.295 \mathrm{mg} / 100 \mathrm{~g}$. Arginina berfungsi meningkatkan daya tahan tubuh, membantu meningkatkan produksi hormon pertumbuhan dan kesuburan pada pria (Linder 1992). Kandungan lisina dan fenialanina hampir sama yaitu masing-

Table 2 Essential amino acids of Amazon sailfin catfish in several inland waters

\begin{tabular}{lrr}
\hline $\begin{array}{c}\text { Essential amino } \\
\text { acids }\end{array}$ & $\begin{array}{c}\text { Amazon sailfin } \\
\text { catfish }(\mathrm{mg} / 100 \mathrm{~g})\end{array}$ & $\begin{array}{r}\text { Requirement according } \\
\text { WHO }^{*}(\mathrm{mg} / 100 \mathrm{~g})\end{array}$ \\
\hline Leucine & 5,780 & 9,300 \\
Arginine & 5,295 & 6,600 \\
Lysine & 4,547 & 7,200 \\
Phenylalnine & 4,454 & 4,300 \\
Threonine & 3,970 & 4,600 \\
Isoleusine & 3,438 & - \\
Valine & 3,390 & 4,200 \\
Methionine & 2,419 & 2,600 \\
Histidine & 2,094 & - \\
Tryptophan & 667 & \\
${ }^{*}$ Requirement essential amino acid according FAO/WHO (Santoso et al. 1996) & \\
& &
\end{tabular}


masing $4.547 \mathrm{mg} / 100 \mathrm{~g}$ dan $4.454 \mathrm{mg} / 100 \mathrm{~g}$, berfungsi sebagai antibodi, memperlancar sistem peredaran darah, menurunkan kadar trigliserida darah (Harli 2008; Abdullah et al. 2017); memproduksi karnitin, yang berperan mengoksidasi asam lemak (Edison 2009). Sedangkan Fenilalanina berfungsi mencegah penyakit gondok (Edison 2009); mengurangi rasa sakit akibat migrain, menstruasi dan arthritis, meningkatnya daya ingat serta dapat mengurangi obesitas (Harli 2008).

Treonina, isoleusina, dan valina ketiganya berjumlah hampir sama yaitu masingmasing $3.970 \mathrm{mg} / 100 \mathrm{~g} ; 3.438 \mathrm{mg} / 100 \mathrm{~g}$ dan $3.390 \mathrm{mg} / 100 \mathrm{~g}$. Treonina berfungsi meningkatkan fungsi hati, jantung dan saraf, mencegah penyakit epilepsi dan meningkatkan kemampuan usus pada proses pencernaan (Harli 2008; Abdullah et al. 2017). Isoleusina berperan antara lain merangsang pertumbuhan, membantu memperbaiki jaringan, meningkatkan kecerdasan, menjaga keseimbangan nitrogen di dalam tubuh, membantu pembentukan asam amino dan hemoglobin serta menetralkan kadar gula darah. Kekurangan isoleusina dapat memicu ketidastabilan gula darah (hipoglikemia) terutama pada penderita diabetes (Harli 2008). Valina berfungsi memelihara jaringan otot, memperbaiki jaringan dan menjaga keseimbangan nitrogen (Harli 2008).

Ikan sapu-sapu mempunyai kandungan metionina dan histidina hampir sama yaitu masing-masing $2.419 \mathrm{mg} / 100 \mathrm{~g}$ dan 2.094 $\mathrm{mg} / 100 \mathrm{~g}$. Metionina merupakan asam amino yang penting untuk metabolisme lemak, memelihara kesehatan hati, mencegah akumulasi lemak dalam hati, pembuluh darah, alergi dan osteoporosis
(Suryaningrum et al. 2010). Histidina berperan untuk pertumbuhan dan perbaikan jaringan (Vijayan et al. 2016). Sumber bahan yang memiliki asam amino dengan konsentrasi rendah dapat disebut sebagai jenis asam amino pembatas (Harris dan Karmas 1989). Jenis asam amino pembatas pada ikan sapu-sapu adalah triptofan yaitu $667 \mathrm{mg} / 100 \mathrm{~g}$. Ikan sapu-sapu memiliki 10 jenis asam amino esensial yang lengkap dan kandungannya yang bervariasi oleh karena itu ikan ini dapat dipilih sebagai sumber bahan penghasil asam amino esensial.

\section{Asam Lemak Esensial}

Asam lemak tak jenuh jamak atau polyunsaturated fatty acid (PUFA), terdiri dari asam linoleat dan asam linolenat (HUFA), asam arakhidonat (AA) dan asam eikosapentanoat (EPA)). Asam lemak tersebut sangat dibutuhkan oleh tubuh dan penting untuk kesehatan (Almatsier 2006). Hasil uji kandungan asam lemak tak jenuh esensial ikan sapu-sapu disajikan di Table 3.

Berdasarkan Table 3, ikan sapu-sapu memiliki asam lemak tak jenuh omega 3 dan omega 6 dengan persentase yang bervariasi. Menurut Peinado et al. (2016), asam lemak tak jenuh jamak seperti omega 3 dan 6 memiliki banyak manfaat di dalam tubuh antara lain meningkatkan kecerdasan khususnya jika diberikan sejak usia dini, menyehatkan jantung melalui perannya memperkuat otot jantung, melenturkan pembuluh darah, mencegah penggumpalan darah serta menurunkan kadar trigliserida darah. Omega 3 berperan meningkatkan fungsi mata dan pencegahan terhadap penyakit kanker (Nurjanah et al. 2015; Dewita et al. 2020; Jacoeb et al. 2020).

Table 3 Essential fatty acids of Amazon sailfin catfish in several inland waters

\begin{tabular}{lc}
\hline \multicolumn{1}{c}{ Parameters } & Results (\%) \\
\hline Omega 3 Fatty Acid & \\
\hline DHA, Decosahexanoac acid & 0.23 \\
EPA, Eicosapentanoic acid & 0.06 \\
HUFA, Linolenic acid & 0.09 \\
\hline Omega 6 Fatty Acid & \\
\hline LA, Linoleic acid & 0.10 \\
AA, arachidonac & 0.15 \\
\hline
\end{tabular}


Kandungan asam lemak ikan sapu-sapu hasil penelitian ini lebih rendah dibandingkan hasil pada ikan sapu-sapu yang berasal dari Sungai Ciliwung yaitu EPA dan DHA masing-masing sebesar 0,22\% dan 2,04\% (Hasanah 2019). Setiap ikan mempunyai komposisi asam lemak yang bervariasi, diduga disebabkan oleh variasi makanannya, habitat, perbedaan jenis kelamin dan keadaan lingkungan (Ozogul et al. 2007).

Setiap ikan memiliki asam lemak tak jenuh bervariasi misalnya pada ikan jelawat memiliki asam linoleat 13,59\%; asam linolenat (HUFA) $=0,27 \%$, asam eikosapentanoat (EPA) $0,23 \%$; asam arakidonat (AA) $1,60 \%$; dan asam dekosaheksaenoat (DHA) 1,1\% (Anggraini 2015). Ikan gindara (Lepidocybium flavobrunneum) memiliki asam lemak linoleat $0,72 \%$; asam dekosaheksaenoat $1,98 \%$; asam lemak arakidonat $=0,72 \%$ (Basmal 2010). Pada ikan layur, tenggiri, tongkol memiliki asam linoleat masing-masing 43,36\%; $0 \%$; $0 \%$; asam arakidonat (AA) masing-masing 0\%; 0\%; 0,94\%; asam eikosapentanoat (EPA) masing-masing $2,41 \% ; \quad 17,44 \% ; \quad 12,27 \%$ (Pratama et al. 2011); ikan molly memiliki asam dekosaheksaenoat 0,09\%; asam eikosapentanoat $0,03 \%$; asam linolenat $0,21 \%$; asam linoleat $0,25 \%$; asam arakidonat $0,04 \%$ (Hasnidar dan Tamsil 2020). Kandungan asam lemak ikan di Indonesia terbilang beranekaragam, hal ini dikarenakan oleh rantai makanan, habitat, dan juga nutrisi yang didapatkan (Abdullah et al. 2015).

\section{KESIMPULAN}

Ikan sapu-sapu mengandung komposisi gizi yang lengkap yaitu protein, asam amino dan asam lemak esensial dengan konsentrasi yang bervariasi, sehingga dapat direkomendasikan sebagai sumber makanan yang bergizi baik untuk konsumsi manusia maupun untuk bahan pakan ikan dan ternak.

\section{UCAPAN TERIMA KASIH}

Penelitian initerlaksana atas bantuan biaya dari Lembaga Penelitian dan Pengembangan Sumberdaya (LP2S) Universitas Muslim Indonesia, diucapkan terima kasih atas bantuan biaya tersebut.

\section{DAFTAR PUSTAKA}

Abdullah A, Nurjanah, Hidayat T, Yusefi Y. 2013. Profil asam amino dan asam lemak kerang bulu (Anadar antiquata). Jurnal Pengolahan Hasil Perikanan Indonesia. 16(2): 159-167.

Abdullah A, Nurjanah, Hidayat T, Aji DU. 2015. Fatty acid profile of jellyfish (Aurelia aurita) as a source raw material of aquatic result rich benefit. International Journal of Chemical and Biomolecular Science. 1(1): 12-16

Abdullah A, Nurjanah, Hidayat T, Chairunisah R. 2017. Karakteristik kimiawi Meretrix meretrix, Pholas dactylus, dan Babylonia spirata. Jurnal Teknologi dan Industri Pangan. 28(1): 78-84.

Adawyah R. 2008. Pengolahan dan Pengawetan Ikan. Jakarta (ID): Bumi Aksara.

Alamatsier Y. 2006. Prinsip Dasar Ilmu dan Gizi. Cetakan keenam. Jakarta (ID): Gramedia.

Anggraini DK, Edison, Sumarto. 2015. Profil asam lemak ikan jelawat (Leptobarbus hoevennii) berdasarkan perbedaan umur panen. Jurnal Online Mahasiswa Faculty of Fisheries and Marine Sciences, University of Riau.

Arias, Garcia, Navarro, Linares G. 2004. Effect of different treatment and storage on the proximate compotition and protein quality in canned tuna. Archivos Latino americanos De Nutriticion. 54(1):112-117.

Astawan M. 2007. Teknik ekstraksi dan pemanfaatan minyak ikan untuk kesehatan. Jurnal Ilmiah Teknologi dan Industri Pangan. 9(1):1-7.

Asnawi. 2018. Uji biologis peranan ikan sapusapu (Hypostomus plecostomus) sebagai pakan itik mojosari. [Tesis]. Fakultas Peternakan Universitas Mataram. .

Aziz AF, Nematollahi A, Siavash, SaeiDehkordi S. (2013). Proximate composition and fatty acid profile of edible tissues of Capoeta damascina (Valenciennes, 1842) reared in freshwater and brackish water. Journal of Food Composition and Analysis. 32(2):150-154.

Batubara UN. 2009. Analisis protein, kalsium lemak pada ikan porapora. [Skripsi] Fakultas Kesehatan Masyarakat 
Universitas Sumatera Utara Medan. Medan.

Basmal J. 2010. Ikan gindara (Lepidocybium flavobrunneum) sebagai sumber asam lemak esensial. Squalen. 5(3): 109-117.

Bell MV, Dick JR, Anderson TR, Pond DW. 2007. Application of liposome and stable isotope tracer techniques to study polyunsaturated fatty acid biosynthesis in marine zooplankton. Journal of Plankton Research. 29:417- 422.

Buckle KA, Edwards RA, Fleet GH, Wootton M. 1987. Ilmu Pangan (Terjemahan oleh Hari Purnomo dan Adiono). Jakarta: UI Press.

Chairunisah R. 2011. Karakteristik asam amino daging kerang tahu (Meretrix meretrix), Kerang Salju (Pholas dactylus), dan Keong Macan (Babylonia spirata). [Skripsi]. Departemen Teknologi Hasil Perairan, Fakultas Perikanan dan Ilmu Kelautan, Institut Pertanian Bogor, Bogor.

Chaidir A. 2001. Pengaruh pencucian daging lumat (minched fish) ikan sapu-sapu (Hypostosmus sp) terhadap kualitas minched fish dalam pembuatan bakso ikan. [Skripsi]. Bogor. Fakultas Perikanan dan Ilmu Kelautan, Institut Pertanian Bogor.

de Carvalho P, Bini LM, Thomaz SM, de Oliveira LG, Robertson B, Tavechio WLG, Darwisch AJ. 2001. Comparative limnology of South American floodplain lakes and lagoons. Acta Scientiarum Maringa. 23(2): 256-273.

DeMan JM. 1997. Kimia Makanan. Edisi ke-2. Terjemahan. Pandamawinata K. Bandung: Penerbit ITB.

Dewita, Syahrul, Hidayat T, Fauzi M. 2020. Karakteristik kimiawi enkapsulasi minyak ikan berbahan baku patin dan hiu dengan penambahan minyak sawit merah. Jurnal Pengolahan Hasil Perikanan Indonesia. 23(2): 342-351.

Dhika LR. 2013. Kandungan Logam Berat Kadmium (Cd) dalam Daging Ikan Sapu-sapu (Pterygoplichthys pardalis) di Sungai Ciliwung. [Skripsi]. Departemen Manajemen Sumber Daya Perairan Fakultas Perikanan dan Ilmu Kelautan Institut Pertanian Bogor, Bogor.
Edison T. 2009. Amino acid: Esensial for our bodies. http://livewellnaturally.com. [diakses 02 Juli 2020]

Elfidasari D, Shabira AP, Sugoro I, Ismi1 LN. 2019. The nutrient content of Plecostomus (Pterygoplichthys pardalis) flesh from Ciliwung River Jakarta, Indonesia. Nusantara Bioscience. 11(1): 30-34.

Gehrke PC. 1990. Spasial and temporal dispersion pattern of golden perch, Macquaria ambigua, larvae in artificial floodplain enviroment. Journal of Fish Biology. 37: 225-236.

Gultom OW, Lestari S, dan Nopianti R. 2015. Analisis proksimat, protein larut air, dan protein larut garam pada beberapa jenis ikan air tawar Sumatera Selatan. Jurnal Teknologi Hasil Perikanan. 4(2): 120-127.

Harris RS, Karmas E. 1989. Evaluasi Gizi pada Pengolahan Bahan Pangan.Terjemahan: Suminar Achmadi. Bandung: Institut Teknologi Bandung (ITB).

Halver JE, Hardy RW. 2002. Fish Nutrition. California (US): Academic Press.

Harli M. 2008. Asam amino esensial. http:// www.suparmas.com. (diakses 14 Juli 2020).

Hasanah M. 2019. Potensi ikan sapu-sapu (Pterygoplichthys pardalis) berbagai ukuran dari sungai ciliwung sebagai sumber asam lemak esensial. [Skripsi]. Program Studi Biologi Fakultas Sains dan Teknologi Universitas Islam Negeri Syarif Hidayatullah, Jakarta.

Hasnidar, Tamsil A. 2020. Karakteristik kimiawi tepung Ikan Molly, Poecilia latipinna (Lesueur 1821). Jurnal Pengolahan Hasil Perikanan Indonesia. 23(2): 392-401.

Hutasoit DY, Yusni E, Lesmana I. 2014. Pengaruh penambahan tepung ikan sapusapu (Lyposarcus pardalis) pada pakan komersil terhadap pertumbuhan ikan patin (Pangasius sp.).

Jacoeb AM, Nurjanah, Hidayat T, Perdiansyah R. 2020. Komposisi kimia dan profil asam lemak ikan layur segar penyimpanan suhu dingin. Jurnal Pengolahan Hasil Perikanan Indonesia. 23(1): 147-157.

Jubaedah I, Sudinno D, Anas P. 2013. Analisis kondisi kualitas air dan produktivitas 
budidaya keramba jaring apung di Waduk Cirata Kabupaten Cianjur Provinsi Jawa Barat.

Junk WJ, Bayley PB, Sparks. 1989. The flood pulse concept in river-floodplain systems. Di dalam: DP DODGE, ed. Proceedings of the International Large River Symposium. Ottawa: Canadian Government Publishing Centre, pp. 110127. Special Publication of the Canadian Journal of Fisheries and Aquatic Sciences, no. 106.

Jumawan JC, Herrera AA, Jumawan JH, Vallejo B. 2016. Size Structure and Reproductive Phenology of The Suckermouth Sailfin Catfish Pterygoplichthys disjunctivus (Weber, 1991) from Marikina River, Philippines. Journal of Agriculture and Biological Science. 11 (1):18-23.

Marwoto RM, Isnaningsih NR. 2014. Tinjauan keanekaragaman moluska air tawar di beberapa situ di das Ciliwung-Cisadane [Study on the freshwater mollusc diversity of the small lakes along ciliwung and cisadane rivers]. Berita Biologi. 13(2):1-9.

Muhtadi A, Dhuha OR, Desrita, Siregar T, Muammar M. 2017. Kondisi, habitat dan keragaman nekton di hulu DAS Wampu, Kabupaten Langkat, Provinsi Sumatera Utara. Depik. 6(2):90-99.

Munandar K, Eurika N.2016. Keanekaragaman ikan yang bernilai ekonomi dan kandungan logam berat $\mathrm{Pb}$ dan $\mathrm{Cd}$ pada ikan sapu-sapu di Sungai Bedadung Jember. Proceeding Biology Education Conference. 13(1): 717-722.

Munthe I, Isa M, Winaruddin, Sulasmi, Herrialfian, Rusli. 2016. Analisis kadar protein ikan Depik (Rasbora tawarensis) di Danau Laut Tawar Kabupaten Aceh Tengah. Jurnal Medika Veterinaria. 10 (1): 67-69.

Nasution SH. 2015. Biodiversitas dan distribusi ikan di Danau Tempe. Prosiding Seminar Nasional Ikan ke 8. Hal 381-392.

Nofdianto, Tanjung LS. 2019. Kerapatan populasi makrofita berpengaruh terhadap kelimpahan dan keanekaragaman mikroalga epifiton di Danau Tempe. LIMNOTEK Perairan Darat Tropis di Indonesia. 26(2):131-151.
Nurjanah, Nitibaskara R, Madiah E. 2005. Pengaruh penambahan bahan pengikat terhadap karakteristik fisik otak-otak ikan sapu-sapu (Liposarcus pardalis). Buletin Teknologi Hasil Perikanan. 3(1):1-11.

Nurjanah, Suseno SH, Hidayat T, Ekawati Y, Paramudhita P, Arifianto. 2015. Change composisition chemical of skipjack tuna due to frying process. International Food Research Journal. 2(5): 2093-2102.

Nurjanah, Jacoeb AM, Hidayat T, Ulma RN, Puspitasari, Hidayat T. 2014. Komposisi kimia kupang merah (Musculista senhausia) segar dan rebus. Depik. 3(3): 241-249.

Nurhayati T, Salamah E, Hidayat T. 2007. Karakteristik hidrolisat protein ikan selar (Caranx leptolepis) yang diproses secara enzimatis. Buletin Teknologi Hasil Perikanan. 10 (1): 23-34.

Ozogul Y, Ozogul F, Alagoz S. 2007. Fatty acid profiles and fat contents of commercially important seawater and freshwater fish species of Turkey: A comparative study. Food Chemistry. 103: 217-223.

Peinado I, Miles W, Koutsidis G. 2016. Odour characteristics of seafood flavour formulations produced with fish byproducts incorporating EPA, DHA and fish oil. Food Chemistry. 212:612-619.

Pratama RT, Awaluddin MY, Ishmayana S. 2011. Komposisiasam lemak ikan tongkol, layur, dan tenggiri dari Pameungpeuk, Garut. Jurnal Akuatika. 2(2):107-115.

Ramlah E, Soekendarsi, Hasyim Z, Hasan MS. 2016. Perbandingan kandungan gizi ikan nila Oreochromis niloticus asal Danau Mawang Kabupaten Gowa danDanau Universitas Hasanuddin Kota Makassar. Jurnal Biologi Makassar (Bioma). 1(1): 39-46.

Rueda-Jasso RA, Campos-Mendoza A, Arreguín-Sánchez F, Díaz-Pardo E, Martínez-Palacios CA. 2013. The biological and reproductive parameters of the invasive armored catfish Pterygoplichthys disjunctivus from Adolfo López Mateos El Infiernillo Reservoir, Michoacán-Guerrero, Mexico. Revista Mexicana de Biodiversidad. 84: 318-326.

Santoso J, Sumaryanto H, Hidayat A, Mulya 
S. 1996. Pembuatan makanan bayi (weaning food) dari campuran tepung beras dan konsentrat protein ikan. Buletin Teknologi Hasil Perikanan. 2(2): 31-42.

Samuel, Makmur S, Pongmasak Pr, Farid A, Adiansyah V, Selamet S, Hifni T, Burnawi. 2010. Kajian stok sumberdaya perikanan di perairan Danau Tempe Sulawesi Selatan. Kementerian Kelautan dan Perikanan Badan Penelitian dan Pengembangan Kelautan dan Perikanan Pusat Penelitian Pengelolaan Perikanan dan Konservasi Sumberdaya Ikan Balai Riset Perikanan Perairan Umum.

Sihite HH. 2013. Studi pemanfaatan limbah ikan dari Tempat Pelelangan Ikan (TPI) dan pasar tradisional Nauli Sibolga menjadi tepung ikan sebagai bahan baku pakan ternak. Jurnal Teknologi Kimia Unimal. 2(2): 43-54.

Suzuki T. 1991. Fish and Krill Protein: Processing Technology. Applied Science. London (UK): Publishers Ltd.

Sun DW. 2006. Thermal Food Processing: New Technologies and Quality Issues. Boca Rason: CRC Press Taylor and Francis Group.

Sumardjo D. 2006. Pengantar Kimia: Buku Panduan Kuliah Mahasiswa Kedokteran dan Program Strata 1 Fakultas Bioeksakta. Jakarta (ID): EGC.

Suryaningrum TD, Muljanah I, Tahapari E. 2010. Profil sensori dan nilai gizi beberapa jenis ikan patin dan hybrid nasutus. Jurnal Pascapanen dan Bioteknologi Kelautan dan Perikanan. 5(2): 153-164.

Stansby ME, Olcott. 1963. Compotition of Fish. Di dalam ME Stansby dan JA Dassow. Editor. Industrial Fisheries Technology. New York (US): Reinhold.

Suhartini S, Hidayat N. 2005. Olahan Ikan Segar. Surabaya (ID):Trubus Agrisarana.
Tanamati F, Stafuzza NB, Gimenez DFJ, Stella AAS, Santos DJA, Ferro MIT, Albuquerque LG, Gasparino E, Tonhati H. 2019. Differential expression of immune response genes associated with subclinical mastitis in dairy buffaloes. Animal. 13:1651-1657.

Trisnawati R. 2007. Pemanfaatan surimi ikan sapu-sapu (Hyposarcus pardalis) dalam pembuatan empek-empek. [Skripsi]. Program Studi Teknologi Hasil Perikanan Fakultas Perikanan dan Ilmu Kelautan. Institut Pertanian Bogor.

Kantun W, Malik AA, Harianti 2015. Kelayakan limbah padat tuna loin madidihang Thunnus albacares untuk bahan baku produk diversifikasi. Jurnal Pengolahan Hasil Perikanan Indonesia. 18(3): 303-314.

Kusharto CM. 2006. Serat makanan dan peranannya bagi kesehatan. Jurnal Gizi dan Pangan. 1(2): 45-54.

Linder MC. 1992. Biokimia Nutrisi dan Metabolisme dengan Pemakaian Secara Kimia. Aminuddin P, Penerjemah. Jakarta: UI Press.

Vijayan DK, Jayarani R, Singh DK, Chatterjee NS, Mathew S, Mohanty BP, Sankar TV, Anandan R. 2016. Comparative studies on nutrient profiling of two deep sea fish (Noepinnula orientalis) and (Chlorophthalmus corniger) and brackish water fish (Scatophagus argus). The Journal of Basic and Applied Zoology. 77: 41-48.

Winarno FG. 2008. Kimia Pangan dan Gizi. Jakarta (ID): PT Gramedia Pustaka Utama.

Wu LW, Liu CC, Lin SM. 2011. Identification of exotic sailfin catfish species (Pterygoplichthys, Loricariidae) in Taiwan based on morphology and mtDNA sequences. Zoological Studies. 50(2): 235246. 